\title{
The Id, Ego and Super-ego in Pride and Prejudice
}

\author{
Yamin Liang \\ English Department, XianYang Normal University, \\ XianYan712000, ShaanXi, China \\ E-mail: liangyamin0102@126.com
}

Received: September 19, $2010 \quad$ Accepted: January 17, 2011 doi:10.5539/ies.v4n2p177

\begin{abstract}
This paper mainly analyses the the id, ego,and super-ego which exists in the main character Elizabeth from several acpects,such as her pursuit for love, her prejudice towards Mr. Darcy, and the changes in her attitudes towards Wickham This analysis helps readers appreciate this mastepiece from a different aspect which is related to the psychological analysis.
\end{abstract}

Keywords: Id, Ego, Super-ego, Psychological analysis

\section{Introduction}

\subsection{A Brief Introduction to the Author}

Jane Austen (December 16, $1775 \sim$ July 18, 1817) is a British woman novelist. Six novels were published in Austin's whole life. Sense and Sensibility (1811) is her first, followed by successive published Pride and Prejudice (1813), Mansfield Garden (1814) and Emma (1815). Northanger Abbey and Persuasion (1818) Pride and Prejudice (1813) which is originally called first impression, is Austen's masterpiece. Through the description of marriage, it shows the life of British society at that time in frame. The stories are about Bennett's daughter's marriages. Mr. Bentley moving from London falls in love with the gentle and the beautiful girl, Jane, that is the eldest daughter among Mr. Bennett's daughters, and Mr. Bentley's friend Darcy fell in love with the second daughter Elizabeth. As she believed with no consideration the young officers Wayne's calumny, she had a prejudice against Darcy. After a series of interesting twists and turns, the misunderstanding finally was removed. At last, Mr. Darcy overcame the arrogance, with Elizabeth overcoming the prejudice against him, and the two people got married in the end.

\subsection{The Definition of "Id, Ego and Super-ego"}

"Id": It is confined primarily to the instinct of survival and nature; the "id" is on behalf of the source of all the "drives". The energy of Personal psychological function is from the instinct of the "life" and "death", or the instinct of the "sex" or "invasion". They are a part of the "id". When they perform their functions, the "id" seeks how to release excitement and tension, then energy. It woks in accordance with the pleasure principle, that is, it tends to pursue the happiness and avoid suffering. According to this mode of operation, the "id" seeks immediately to release the energy completely. The "id" can not stand any setbacks, and has no scruples. In a word, the "id" is excessive, impulsive, blind, irrational, non-social, selfish, and is to indulge in pleasure.

"Ego": It is on behalf of reason and good will. The "id" chases after the pleasure, and the "super-ego" is in pursuit of the "perfect", but the function of the "ego" is to satisfy the desire of the "id" and the requirement of the "super-ego" in accordance with reality principle. The "id" works according to the "happiness principle", and the "ego" works according to the "reality principle"- the instinct is delayed until to meet the appropriate time, so most pleasure contains minimal pain and negative results. The "ego" is able to separate the desire from the fantasy, tolerate stress and compromise, and can change over time.

"Super-ego": It can be regarded as the moral of the "ego". Super-ego highlights two aspects; conscience and ego-ideal. The opposite of the "id" is the super-ego, that is, it is the branch of human psychology and moral function, and it contains those concepts we're working for and the expected guilty when we go against our code of ethics. This part of the structure of personality is based on community standards to control the behavior and to perform its functions, rewarding good behavior (Pride, self-love), and punishing the bad behavior (guilt, inferiority, accident). The super-ego plays the function in the primitive level, so it can not stand the test of reality relatively, that is, can not change one's actions in different atmosphere. 


\section{The Expression of Elizabeth's "Id"}

\subsection{The Background of the Family}

In the early twentieth century and the late nineteenth century, the United Kingdom's industry is still not very well-developed and agriculture and animal husbandry which accounts for the main location is overruled by the Aristocracy. In the poor class of the whole society, the vast number of people is suffering from a variety of class exploitation, particularly in the aspect of land-based. The majority of people due to the lack of land are being affected by cold and hunger, and the survivorship of the reality and the future are threatened seriously. In order to survive, in order to please the nobles, and letting the Aristocracy give them the right of life, in the card table, "Mr. Collins was employed in agreeing to every thing her Ladyship said, thanking her for every fish he won, and apologizing if he thought he won too many. Sir William did not say much. He was storing his memory with anecdotes and noble names." The survival is everyone's first choice, especially for the people that are the poor and lack of materials. In other words, the will to live has been ingrained in everyone's heart. The good personal qualities, the so-called rational understanding of things about the "id", the ego-ideal, ect, and the "super-ego" are nearly meaningless at this time, but the will to live about the "id" still impose everything on the "ego". Under the power of the "super-ego" at the same time, the "id" is so pitiful. In other words, the "id" is equivalent to the external environment, the "ego" equivalent to the rider, and the "super-ego" equivalent to the horse; so the rider has to choice the right direction by his rational ideas under the force of the "external environment and horse". The background information of the middle-class families of Long bourn, Elizabeth's family, is that there is no brother, with only five sisters, father and mother; the father has nearly $£ 2000$ income only a year that is just enough to the family one year's expenditure, but "According to Will on the additional terms, this industry must be passed to male heirs, the Bennett's couple had no sons, so that the industry should be inherited by a distant relative." For this reason, the additional terms pushes the five sisters to the Abyss; and in this kind of background, in order to live, the only choice of the five sisters is marriage. Therefore, Elizabeth and her sisters finally choose the "bread", or choose a passage of romantic love, which let her get the achievement. At this time, the "id", the "ego" and the "super-ego" intertwine with each other in conflict and contradiction for the innocent woman that Elizabeth.

\subsection{The Need of the Survival of Elizabeth}

\subsubsection{Her Pursuit for the Material}

The survival instinct derives from pairs of material; and the survival of depression is from the society where is turbulent, and from the torture of the disease. However, the more important factor is depended on the means of subsistence. Elizabeth, who is born in the middle-class family which is located in the town called Long bourn, seems have not to worry about the problem of the survival, and in the future, she will have seemly good living condition. According to this point, her id has surpassed and gone directly. It shows that she can choose everything rationally, meanwhile, with the leading of the consciousness of the "super-ego", she can get her the achievement of "ego-ideal". However, according to the additional property terms, Elizabeth can not inherit the estate of the Bennett's and under the background of the society that is turbulent and dark, there is a serious problem about the survival in the future for lacking of material to her. In order to survive, the enough living materials are the essential and the safeguard to everyone. However, no one can give any right answer to the problem in the future .That is, it is Elizabeth that has the same boat with other people who are living in that kind of society, which is turbulent and governed by the Aristocracy. In a word, the story in this book shows that the living materials are so important in that time, so everyone is so eager to get it, but environment threats the survival of the people. In other words, it suppresses the "id". The wealth of experience and knowledge makes the "ego" going into the "super-ego". In this case, it makes the willingness to live, the ego-ideal, the conscience, and the love intertwine with the unconscious instinct of survival.

\subsubsection{The Sustenance of Her Spirit}

"Source devoting much anxiety to seek a way of venting is due to the potential direct inhibitory effect of the fate of'[5], a depression in of the survival of people will have to find ways to release, but the way Elizabeth chooses is marriage, so that she can seek a greater spiritual sustenance, and make the pressure of the survival find a new way out in the future.

So in the future of extreme shortage of supplies, in order to survive, the only way out for Elizabeth is to get married, but this marriage is not only with emphasis on "physical needs" and "security needs". If so, Elizabeth's refusal to the Corserine priest's offer dose not seems to be reasonable in. She established the pursuit of the love at a higher level. That is said she has overcome the limitation of id and ego and gone directly in to the state of super-ego.

Therefore, Elizabeth can marry a husband who shares love with her in emotion and physically wealthy so that she do not take account of problem of "the survival", then the pent-up feeling of in such a life, she will have greatly 
sustenance, and finally the "physical needs" about the "id" will be resolved. Through the development of the story, Mr. Darcy is better served this kind of role in this story. As Elizabeth said:" I love him, he is not proud, I was wrong before, entirely wrong about him." So, this shows what Elizabeth chases after is the sustenance of the spirit.

Therefore, the instinct in the "id" is embodied vividly. The character is under pressure of id, with the id finding a new way out under the limitation of super-ego. This will make the three intertwined in the conflict and contrition. In addition to this, Elizabeth dose not accept the first offer of Mr. Darcy once again proved that in Elizabeth's consciousness, the desire to get the advanced needs is so strong. The judgment that Elizabeth makes to Mr. Darcy is true, completely coming from her own feelings, and will not be changed because of Mr. Darcy's property, his social status and the living materials. However, Darcy's disgust for her family and relatives anomies her when he proposed to her for the first time. Elizabeth thinks that Darcy is in fact to "violate her" "insult her", so that she can not go to make comprises, regardless of dignity and promise this marriage. In the subconscious of Elizabeth, the need to "love", the desire to the ultra-high aspirations once again makes the "id", the "ego", the "super-ego" intertwined with each other in the conflict and contradiction.

\section{The Expression of Elizabeth's "Ego"}

\subsection{Feelings of Frustration}

If external things make a person get hurt, he or she is bound to be afraid of the external things emotionally. Mr.Bingly who is born in aristocracy rents the Niger Longurn, which is the symbol of wealth. That is simply incredible for the poor. As Mrs. Bennett said:" my dear, Mr.Bennet, have heard that someone is going to rent Nether field park at last?" "Well, my dear, I hear that he's a very rich young man from the north of England. It seems he came to see Nether field on Monday and was so delighted with it that he arranged to rent it at once. Of course, it is the finest house in the area with the largest gardens. His servant will be here by the end of the week, and he will be arriving soon afterwards!" . The instinct of the survival that is in the "id", imposes the people to get close to the rich man, "if he picks one of our daughters as his wife, that is may be more than good". This kind of unconscious state drives people to convert it to a conscious one, so that in the first ball, the "ego" that is reflected in the unconscious state derives, Elizabeth, consciously who got close to Mr.Bingley's friend, Mr. Darcy. Kind nature makes Elizabeth politely invite Mr. Darcy who has 10,000 pound income a year, and is so handsome to dance. However, well-born Mr. Darcy's attitude humbles Elizabeth's feelings, making "the ego the ultra-stringent under the ethical standards of super-ego"; Making this kind nature be destroyed completely under the conscious state of super-ego that is full of love and ideal; Making the "id", "ego" and "super-ego" intertwine with each other again in conflict and contradiction. Elizabeth was hurt seriously at this time so that Elizabeth had a serious prejudice to Mr. Darcy. Kind-hearted nature of the "id" no longer believes that Mr. Darcy will be a good man. As she says: "I do not believe a word of it, my dear. If he had been so very agreeable, he would have talked to Mrs. Long. But I cangues how it was; every body says that he is ate up with pride, and I dare say he had heard somehow that Mrs. Long does not keep a carriage, and had come to the ball in a hack chaise". "The super-ego is also the vector of the ego ideal, the ego accesses itself according to the super-ego, trying its best to imitate the super-ego, and trying to make the super-ego satisfied with the requirement and make it be perfect". However, this kind of awareness of the ego ideal is obliterated instantly by kinds of factors of the external environment . But it does not show that the main character, Elizabeth, does not lose the ego of the good will of going on exploring the true love from then on, but merely a temporary suppression which is from the character Elizabeth's heart, and this kind of the temporary suppression will keep on driving Elizabeth to get longingly the consciousness of the super-ego which is "Care, respect, understanding". So, "We prefer to believe the pent up contents have a powerful force which can go upward strongly, and have the impulse of the consciousness of entering. Resistance can only be manifestation of the "ego", and it puts repression into practice at first, and now they still want to keep suppressed".Therefore, it makes the "ego" be reflected from the "id", and the super-ego involve in the "ego". These three factors interacting with each other make the protagonist Elizabeth have a depressing feeling, and make her struggle with herself constantly in her heart.

\subsection{Seeing through Lies}

"Super-ego imposes the most stringent ethical standards on the helpless ego, and under the menace of the super-ego, the ego is so pitiful." After the character Elizabeth is depressed emotionally, "the original desire is vented with in a way of anxiety." The anxiety being from the "id" drives Elizabeth to seek a way out. That is to find another love or some way. This will make her own good heart strong since then, making the "ego" no longer bound up by super-ego, and then make the "ego" be understood, finally achieve the "super-ego" after being taken care of. In a number of factors, Elizabeth chooses empathy, and this instinctive sense of empathy comes from the unconscious state, so she was immediately attracted by the appearance of the officer Wickham coming from the self-defense groups. The cunning Wickham's and Elizabeth feel like old friends at the first sight. He pours out words in a steady flow in order to wash away his sin and slander Darcy. "that he or that any man should not be estimated beyond their deserts; but 
with him I believe it does not often happen. The world is blinded by his fortune and consequence, or frightened by his high and imposing manners, and sees him only as he chases to be seen" and Elizabeth that is so clever, can't be aware what Wicham says is a complete lie. She is governed to totally by Wicham, so she is led by Wickham. Perhaps the self-repression allows Elizabeth to produce a super-emotional impulse, making her totally be. "Mr.Wickham in terms of character, the appearance, demeanor, the status, is far more than them." Her good quality, is deceived by the lies from outside. A temporary psychological care seems to have been obtained sustenance. Lie is a lie. After all, in Mr. Darcy's letter "of what he has particularly accused me, I am ignorant; but of the truth of what I shall relate, I can summon more than one witness of undoubted veracity. Mr. Wickham is the son of a very respectable man, who had for many years the management of all the Pemberley estates you may imagine what I felt and how I acted. Regard for my sister's credit and feelings prevented any public exposure, but I wrote to Mr. Wickham, who left the place immediately, and Mrs.Younge was of course removed from her charge. Mr. Wickham's chief object was unquestionably my sister's fortune, which is thirty thousand pounds; but I cannot help supposing that the hope of revenging himself on me was a strong inducement." Of course, after reading, the main character, Elizabeth can not trust it. With a good nature, she dose not know whom she can believe. At that moment, ego and super-ego once again intertwine with each other in conflict and contradiction. The ego forces Elizabeth to consciously testify what Mr.Darcy has said under the pressure of super-ego. The result is that all the lies Wicham says have been recognized. At this time, Elizabeth begins to realize, that, Mr. Darcy has been admiring her, but because of the compulsion of the consciousness of the "instinct", it makes "himself" get in trouble. As Freud said, "I succumbed to an overly strong desire to seek pleasure, and thus do some things against their conscience, and then my conscience punish me with a painful blame and let me feel shame of that this behavior shame." This is super-ego. In this case, Elizabeth began to judge Mr.Darcy again through her rational point of view. The "ego" has been relieved slightly at this time and it entered the super-ego state.

\section{The Expression of Elizabeth's "Super-ego"}

\subsection{Accepting the Offer}

As the owner of the Pemberley that is a promise estate industry, Mr. Darcy wins the crowd's attention from the very beginning: his burly stature, the delicate features, and noble manners. Therefore, less than five minutes when he arrives at the scene, all the people have a legend of his annual income of ten thousand pounds. Gentlemen praise him for a man of striking, the ladies thinking he is more handsome than Mr.Bingley. People have been looking at him with eyes of love for almost half of the night. Such a gentleman who enjoyes popular confidence is naturally proud, and he is also eligible for pride. However, that is, such an elegant gentleman, because of the sexual impulses of the "id", and the rational analysis of the "ego", with the consciousness of the "super-ego", he designs to pour out love to Elizabeth. However the expression hurts Elizabeth's feelings and he is blamed by her. This have a sense of inferiority in front of his loved one, which result in fearing of love for being full of misgivings, afraid to let go in pursuit of true love.

Loving at first sight of Mr. Darcy, Elizabeth has a prejudice because of Darcy's arrogant attitude and it makes each other's emotion reach impasse. The realization of the ego-ideal is often driven by the "id", and is limited by the "super-ego". As Freud said, "the ego is driven by the id, and is constrained by the super-ego, and is excluded by the reality, for struggling for the economic task that is not completed, so that it can guide all kinds of power and influence to achieve harmony". [3] The character Elizabeth is in pursuit of love, "which is engaged in fierce struggle in her heart, and is finished although there are under the rapid sublimation effect and the agreement". [4] Super-consciousness, forces her re-evaluate this gentleman. Therefore, after realizing the lies of Wicham, the understanding to Mr.Darcy and the super-consciousness of the love to him take shape instantly, "if I love you little, we can talk more" "It is a coincidence, your answer always makes sense, I also understand the reason why this happens, and admit this answer", for this reason, Darcy's second suitor is accepted logically.

Elizabeth's family background is similar to Charlotte's family, her "physical needs" (survival needs) and the "security needs" should be the same as Charlotte that is urgent to be met. However, she has not thought simply marriage as sources of access to food, clothing and security. She was very seriously declined Collins's proposal of marriage, giving up a great opportunity to meet her "physical needs" and "security needs". This shows that, in Elizabeth's consciousness, her need for a rank level is different from the general one. Her concept of values is different from the other people's concept which is to tend to worship different substances, highlighting the need for higher levels which is the spiritual one. This has a very obvious noble nature: "people with such values will become martyrs for their pursuit of an ideal or value because they can give up everything".[6] Elizabeth rejects Darcy's marriage proposal for the first time. It once again proves that in her consciousness, how strongly the desire to meet the advanced needs is! The judgment that is to re-judge Darcy is entirely out of Elizabeth's own personal feeling. It will not be changed because of his property, the status of the material which can give her the satisfaction. When Darcy reveals a marriage proposal to her, he despises her relatives, the family' which, makes her very objectionable. Elizabeth thinks that Darcy is in fact to "violate" her, "insult" her. Her strong "self-esteem needs", which makes her 
not go to make compromises, and promise that marriage regardless of dignity.

\subsection{Happy Marriage}

"My feeling and hope is still the same, but as long as you never mentioned a word I would, if, in any case, if you change your mind, I must tell you that you have captured my soul and body, I love ... ... I love ... ... I love you! From now, I do not want to separate with you!" when Elizabeth agrees to Darcy's second marriage proposal, his "love needs" and "self-esteem needs" have been met. The ego changes into the super-ego and then the ego-ideal is also achieved. The love she has accepted a mature love, and her love is built on the mutual understanding, care, responsibility and respect. In her more contact with Darcy, she gradually realizes that "he is the most suitable man for her in all aspects. Even if his views, his temper, are not as same as hers, they must be able to call her bed of roses." In addition, everything that Darcy does about Lydia is enough to make him deserve respect in dealing with different things. Finally, Elizabeth has a powerful speech with Lady Catherine for the lady obstructs Elizabeth to be with Mr. Darcy, "your nephew is a gentleman, I am a gentleman's daughter, we are all well-matched". This also proves that she is satisfied with "self-esteem needs" in love. Because the real love "is to maintain their dignity and individuality under the premise of the behavior of emotional exchange," "Love acknowledges the value of their own and keeps one's own dignity and individuality." The character Elizabeth sticks to her outlook in life, values, love. The overcoming of id, the satisfaction of ego, and the realization of super-ego intermingling with each other which makes the protagonist Elizabeth acceded to the final, happy marriage.

\section{Conclusion}

Such comments in French historian Andre • Bierjiai's family history are about the eighteenth and nineteenth-century England Marriage: "Love in the realities of marriage is doomed to be a compromise to reality and gets its power, in the fictional literature". The combination of Darcy and Elizabeth is gave an obvious literary idealistic style. It is not difficult to find that their emotional entanglements are occurred between the "love need" and "self-esteem" from Humanistic Psychology, and eventually, love harvests its fruit from mutual respect -marriage. Although the "ego" seems pitiful under the harsh conditions of the "id" and under the abusive practices of the super-ego seems pitiful, but the awareness of the "id" that is the need to survive, and super-consciousness of love, finally has to be reflected through rationality and the good quality. "Physiological needs" and "spiritual needs" eventually make the two protagonists be in love for all seasons.

Therefore, on the road of pursuing love, we must strengthen our faith, and do not make impulsive decision just because of money, fame and fortune, etc. we should persist in uphold the search for true love. If the other side has some of the shortcomings which you can not tolerate, and he can not change, you should give up resolutely. Of course, you should cherish each other, not because you can not change the decision, but because the happiness is to be managed by yourself.

\section{References}

Bush, Douglas. (1975). Jane Austen. New York: Macmillan Publishing.

Cavell, M. (1980). The Psychoanalytic Mind: From Freud to Philosophy. Harvard University Press, 1993. Chessick, R.D. Freud Teaches Psychotherapy. Hackett Publishing Company.

Corpland Edward \& Mcmaster Juliet. (2001). The Cambridge Companion to Jane Austen, Shanghai Foreign languages Press.

Freud. (1967). Encyclopedia of Philosophy, vol. 3 (ed. P. Edwards). Collier Macmillan.

Freud, Sigmund. (1923). "Neurosis and Psychosis". The Standard Edition of the Complete Psychological Works of Sigmund Freud, Volume XIX (1923-1925): The Ego and the Id and Other Works, 147-154

Gay, Peter. (ed., 1989). The Freud Reader. W.W. Norton.

James Edward. (1985). Memoir of Jane Austen. London: Macmillian Education.

Jane Austen., (1978). Pride and Prejudice. London: Oxford University.

Kurt R. Eissler. (1953). The effect of the structure of the ego on psychoanalytic technique republished by Psychomedia.

Rangjung Dorje (root text) (1978). Peter Roberts (translator) (2001) London: Oxford University.

Roe Sue \& Sellers Susan. (2001). The Cambridge Companion to Virginia Woolf, Shanghai Foreign Language Education Press.

Schafer, R. (1976). A New Language for Psychoanalysis. Yale University Press. 